\title{
Effect of Fasting on Adipose Tissue Weight in Chicks, with Reference to Changes in Chemical Composition and Lipase Activity
}

\author{
Shin Hasegawa, Tomohiro Kawakami, Kazuhisa Honda \\ and Yuzo HikamI \\ Laboratory of Nutritional Biochemistry, Department of Animal Science, \\ Faculty of Agriculture, Kobe University, Nada-ku, Kobe-shi 657
}

(Received June 2, 1993)

\begin{abstract}
The effect of fasting on adipose tissue weight was investigated in growing chicks. Fasting considerably decreased the wet weight of adipose tissue by decreasing the dry matter content per deoxyribonucleic acid. The decrease in dry matter content was mainly associated with the decrease in triglycerides, a major component in the adipose tissue, Both the activities of lipoprotein lipase (LPL) and hormone-sensitive lipase (HSL) were reduced markedly by fasting. An approximate $60 \%$ decrease in the plasma triglyceride concentration was induced by fasting. Fasting markedly decreased the incorporation of ${ }^{14} \mathrm{C}$-acetate into fatty acids and of ${ }^{14} \mathrm{C}$-palmitate into triglycerides in the liver in vivo and in vitro, whereas the ${ }^{14} \mathrm{CO}_{2}$ expiration from $\left[11^{-14} \mathrm{C}\right]$ palmitate in vivo and in vitro was increased by fasting. The mechanisms of triglyceride diminution in the adipose tissue of chicks by fasting is discussed.
\end{abstract}

Anim. Sci. Technol. (Jpn.) 65 (2) : 89-98, 1994

Key words : fasting, chick, adipose tissue accumulation, liver, triglyceride metabolism

It is generally accepted that fasting induces a marked decrease in body fat content in both avian species and mammals ${ }^{3,8,17,39)}$. In mammals, there have been a number of studies on the influences of fasting on body fat deposition ${ }^{6,711,15.20,26-31,35)}$. PAIK and YEARICK ${ }^{28)}$ have proposed that one mechanism, other than de novo lipogenesis, in fat deposition is a change in the relative activities of LPL, which mediates the uptake of fatty acid from plasma triglyceride, and HSL, which mediates the output of fatty acid from adipose tissue triglyceride, in adipose tissue. On the contrary, in avian species, little information is available as to the mechanisms by which fasting reduces body fat, because the studies on hepatic lipid metabolism have been of particular interest by reason that lipid synthesis in chicks is mostly restricted to the liver. Since avian adipose tissue, differing from mammalian adipose tissue, has a very low lipogenic activity ${ }^{21,25,37)}$, fat deposition in this tissue seems to be regulated mainly by the above two lipase systems. Although the influences of fasting on triglyceride metabolism in the liver have been well studied ${ }^{10,22,32,36,37)}$, there is only limited information on the interrelationship between triglyceride synthesis and fatty acid oxidation in the liver of chicks treated by fasting.

This investigation was carried out to determine the changes made by fasting in the chemical composition, lipid composition and two lipase (LPL and HSL) activities in the adipose tissue of growing chicks. In addition, we investigated these changes by fasting via triglyceride synthesis and fatty acid oxidation in 
the liver.

\section{Materials and Methods}

Animals and design: Male Single-Comb White Leghorn chicks were used and fed a commercial chick starter ration from one day old to 21 days of age. Three experiments were carried out. In experiment 1, 21 day-old chicks were allocated into 4 groups of 4 chicks each, One group was fed ad libitum a commercial chick starter ration for 3 days. The other three groups were deprived of food for 1 , 2 and 3 days, respectively. At 24 days of age, the chicks were provided for lipase assay and chemical analysis. In experiment 2,21 day-old chicks were allocated in to 2 groups of 4 chicks each. One group was fed ad libitum a commercial chick starter ration for 2 days. The other group was deprived of food for 2 days. At 23 days of age, the chicks were provided for chemical analysis and lipase assay. In experiment 3,21 day-old chicks were allocated into 2 groups of 4 chicks each. One group was fed ad libitum a commercial chick starter ration for 2 days. The other group was deprived of food for 2 days. At 23 days of age, the chicks were provided for determinations of triglyceride synthesis and fatty acid oxidation. Water was provided freely at all times. Room temperature was maintained at $24 \pm 2^{\circ} \mathrm{C}$.

Lipase assay and analytical procedure: At the end of the experiment, the chicks were decapitated and the abdominal adipose tissue was immediately excised together with the peritoneum. The tissue sample was weighed, minced with scissors and taken for lipase (LPL and HSL) assay and chemical analysis. Blood was collected into a heparinized tube and centrifuged at $2,000 \times \mathrm{g}$ for 10 minites within 30 minutes after the collection. The plasma sample was stored at $4^{\circ} \mathrm{C}$ pending analysis.

LPL activity was assayed as described previously ${ }^{12)}$. The minced sample was homogenized in 100 volumes of ice-cold acetone, using a Waring blender. This suspension was filtered through No. 2 filter paper (Toyo Roshi Co.) on a Buchner funnel and washed successively with $100 \mathrm{~m} l$ of acetone and $100 \mathrm{~m} l$ of diethylether at room temperature. The residue on the filter was dried for 1 hour in vacuo at $4^{\circ} \mathrm{C}$. Ten $\mathrm{mg}$ of dried material was scraped from the filter paper into $15 \mathrm{ml}$ of ice-cold 0.025 $\mathrm{M} \mathrm{NH_{4 }} \mathrm{OH}$ and extracted at $0^{\circ} \mathrm{C}$ for 1 hour with stirring. The extract $w$ as centrifuged at 15,000 $\times g$ at $0^{\circ} \mathrm{C}$ for 30 minutes. The clear supernatant was used for activity assay. The LPL activity was determined by measuring the amount of free fatty acid released by hydrolysis of an artificial triglyceride emulsion (ediol, Calbiochem. Co.) activated by preincubation with starved fowl serum. HSL activity was assayed as described previously ${ }^{12)}$. The minced sample was homogenized in 6 volumes of $0.25 \mathrm{M}$ sucrose ( $\mathrm{pH} 6.8$ ) containing $1 \mathrm{mM}$ EDTA, using a Waring blender. The homogenate was centrifuged at $12,000 \times \mathrm{g}$ at $0^{\circ} \mathrm{C}$ for 30 minutes. The fat cake of the upper phase was carefully removed and the supernatant fluid of the medium phase was used for activity assay. The HSL activity was determined by measuring the amount of free fatty acid released via the hydrolysis of ediol. The activities of both LPL and HSL were expressed as $\mu \mathrm{mol}$ fatty acid released per hour per mg DNA.

Minced samples were taken for determining of DNA, mositure, lipid and protein content. DNA content was determined via the method described by BurTon ${ }^{5}$. Moisture content was determined by drying the sample at $135^{\circ} \mathrm{C}$ for 2 hours. Protein content was estimated from nitrogen content which was determined by a micro-Kjeldahl method. Lipid was extracted with a chloroform-methanol mixture $(2: 1, \mathrm{v} /$ v), washed with $0.04 \% \mathrm{MgCl}_{2}$ solution to remove nonlipid substances via the method of Folchet al.9) and then determined gravimetrically. Suitable portions of total lipid were taken for determining the triglyceride, phospholipid, total cholesterol and free fatty acid content. The plasma total lipid was ex- 
tracted from the plasma sample and determined by the method of BRAGDON ${ }^{4)}$. Suitable portions of the total lipid were taken for determination of each lipid component.

Triglyceride synthesis and fatty acid oxidation determinations: In vivo triglyceride synthesis and fatty acid oxidation were determined by the procedure described in a previous paper ${ }^{14}$. At the end of the experiment, each chick was intravenously administered with $0.2 \mathrm{~m} l$ of either saline containing $4 \mu \mathrm{Ci}$ sodium $\left[1{ }^{14} \mathrm{C}\right]$ acetate $(53 \mathrm{mCi} / \mathrm{mmol}$, Amersham, Bucking. hamshire, UK.) or a suspension containing $4 \mu \mathrm{Ci}$ palmitate-bovine serum albumin complex prepared using $\left[1-^{14} \mathrm{C}\right]$ palmitate $(50 \mathrm{mCi} / \mathrm{mmol}$, Amersham, Buckinghamshire, UK) ${ }^{13)}$. Immediately after the administration, each chick was placed in a plastic box equipped with two glass tubes, $\mathrm{CO}_{2}$-free air was passed through one tube at a constant rate and through the other tube expired $\mathrm{CO}_{2}$ was trapped in a mixture of ethanolamine and methylcellosolve (1: $2, \mathrm{~V} / \mathrm{V})$ for 10 minutes. Ten minutes after the administration of the isotope, the chick was killed by decapitation and the liver was rapidly removed, weighed and used for the determination of synthetic rates. The rates of in vivo fatty acid synthesis from acetate and triglyceride synthesis from palmitate were expressed as dpm per mg of DNA. The rate of in vivo palmitate oxidation to $\mathrm{CO}_{2}$ was expressed as dpm per $100 \mathrm{~g}$ of body weight per 10 minutes.

In vitro triglyceride synthesis and fatty acid oxidation were determined by the procedure described in a previous paper ${ }^{14)}$. At the end of the experiment, chicks were killed by decapitation, and the livers were rapidly removed, weighed and chilled. Liver slices weighing 100 to $150 \mathrm{mg}$ were prepared in the cold with a Stadie-Riggs handmicrotome, rinsed in an icecold $\mathrm{NaCl}$ solution $(0.9 \%)$ and used for the determination of synthesis. The rates of in vitro fatty acid synthesis from acetate, triglyceride synthesis from palmitate and palmitate oxida- tion to $\mathrm{CO}_{2}$ were expressed as nmoles of substrates converted to products per mg of DNA per 2 hours.

Statistical treatment: The statistical significance of the difference between means was analyzed using the Student's t-test.

\section{Results}

Experiment 1: The change in the abdominal adipose tissue weight during 3 days of fasting is shown in Table $1 \mathrm{~A}$. On the 1st day of fasting, the tissue weight began to decrease and attained $26 \%$ of the weight of the fed group on the 2 nd day. There was no significant difference in the tissue weight between a 2 -day and a 3-day fasting. In the following experiments, therefore, the abdominal adipose tissue from chicks subjected to 2 days of fasting was used. As shown in Table $1 \mathrm{~A}$., the plasma free fatty acid concentration increased markedly on the 1st day, but decreased gradually from the 2 nd day. By the 3rd day of fasting, it returned to pre-fasting level. The LPL/HSL activity ratio showed no change during 3 days of fasting (Table $1 \mathrm{~B}$ ).

Experiment 2: The changes in body weight, adipose tissue weight and adipose tissue DNA content by fasting are shown in Table $2 \mathrm{~A}$. The weight of body and adipose tissue decreased $20 \%$ and $60 \%$ by fasting, respectively, although adipose tissue DNA concent was not affected. The changes in chemical composition of the adipose tissue by fasting are shown in Table $2 \mathrm{~B}$. The dry matter content per mg DNA decreased $59 \%$ by fasting. Although the moisture content per mg DNA showed a $37 \%$ decrease, the percentage of this component to the wet weight was only $20 \%$ or less. The lipid content per mg DNA showed a $59 \%$ decrease by fasting. Although the protein content showed a $68 \%$ decrease, the percentage of this component to dry matter was only about $10 \%$. The change in lipid composition of the adipose tissue by fasting is shown in Table 3. The triglyceride content per DNA, 


\section{Hasegawa, Kawakami, Honda and Hikami}

Table 1. Effect of fasting on body weight, abdominal adipose tissue weight, plasma FFA concentration (A), and the activities of lipoprotein lipase (LPL) and hormone-sensitive lipase (HSL) in the abdominal adipose tissue (B) (Experiment 1)

(A)

\begin{tabular}{|c|c|c|c|c|}
\hline \multirow{2}{*}{ Treatment } & \multirow{2}{*}{$\begin{array}{c}\text { Body weight } \\
(\mathrm{g})\end{array}$} & \multicolumn{2}{|c|}{ Adipose tissue weight } & \multirow{2}{*}{$\begin{array}{l}\text { Plasma FFA } \\
(\mu \mathrm{Eq} / 100 \mathrm{ml})\end{array}$} \\
\hline & & $(g)$ & $(\mathrm{g} / 100 \mathrm{~g} \mathrm{BW})$ & \\
\hline Fed & $247 \pm 5$ & $2.62 \pm 0.22$ & $1.06 \pm 0.03$ & $36.10 \pm 4.87$ \\
\hline Fasted, 1 day & $217 \pm 3^{* *}$ & $1.14 \pm 0.31^{* *}$ & $0.53 \pm 0.01^{* *}$ & $65.73 \pm 1.57^{* *}$ \\
\hline Fasted, 2 days & $196 \pm 2^{* *}$ & $0.67 \pm 0.12^{* *}$ & $0.34 \pm 0.04^{* *}$ & 53. $41 \pm 2.00^{*}$ \\
\hline Fasted, 3 days & $183 \pm 4^{* *}$ & $0.61 \pm 0.06^{* *}$ & $0.33 \pm 0.03^{* *}$ & $40.09 \pm 4.72$ \\
\hline
\end{tabular}

(B)

\begin{tabular}{lccc}
\hline Treatment & LPL & HSL & $\begin{array}{c}\text { LPL/HSL } \\
\text { activity raito }\end{array}$ \\
\cline { 2 - 3 } & $237.8 \pm 16.5$ & $17.81 \pm 0.72$ & $13.35 \pm 1.14$ \\
Fed & $88.5 \pm 8.9^{* *}$ & $8.22 \pm 1.14^{* *}$ & $10.77 \pm 0.48$ \\
Fasted, 1 day & $35.5 \pm 18.5^{* *}$ & $3.41 \pm 0.63^{* *}$ & $10.41 \pm 0.79$ \\
Fasted, 2 days & $27.0 \pm 3.3^{* *}$ & $2.33 \pm 0.32^{* *}$ & $11.59 \pm 1.81$ \\
\hline
\end{tabular}

Values are means \pm S.E.M. of four chicks. * : Significant with respect to fed chicks. $(0.05>P>$ $0.01)$.*: Significant with respect to fed chicks. $(P<0.01)$.

Table 2. Effect of fasting on body weight, abdominal adipose tissue weight, abdominal adipose tissue DNA content (A) and chemical composition of the abdominal adipose tissue (B) (Experiment 2)

(A)

\begin{tabular}{lccc} 
Treatment & $\begin{array}{c}\text { Body weight } \\
(\mathrm{g})\end{array}$ & $\begin{array}{c}\text { Adipose tissue } \\
\text { weight } \\
(\mathrm{g})\end{array}$ & $\begin{array}{c}\text { Adipose tissue } \\
\text { DNA } \\
(\mathrm{mg})\end{array}$ \\
\hline Fed & $241 \pm 5$ & $2.76 \pm 0.02$ & $1.091 \pm 0.068$ \\
Fasted & $192 \pm 1^{* *}$ & $1.11 \pm 0.12^{* *}$ & $1.005 \pm 0.118$ \\
\hline
\end{tabular}

(B)

\begin{tabular}{|c|c|c|c|c|c|}
\hline Treatment & Moisture & Dry matter & Lipid & Protein & Residue \\
\hline & \multicolumn{2}{|c|}{$(\mathrm{mg} / \mathrm{DNA})$} & \multicolumn{3}{|c|}{ (mg/DNA) } \\
\hline Fed & $353 \pm 52$ & $2177 \pm 185$ & $1894 \pm 213$ & $252 \pm 24$ & $31 \pm 4$ \\
\hline \multirow[t]{2}{*}{ Fasted } & $222 \pm 15$ & $882 \pm 111^{* *}$ & $779 \pm 134^{* *}$ & $80 \pm 11^{* *}$ & $23 \pm 4$ \\
\hline & \multicolumn{2}{|c|}{ ( $\%$ of wet weight) } & \multicolumn{3}{|c|}{ ( $\%$ of dry matter) } \\
\hline Fed & $14.0 \pm 1.7$ & $86.0 \pm 1.6$ & $87.0 \pm 2.1$ & $11.6 \pm 1.1$ & $1.4 \pm 0.1$ \\
\hline Fasted & $19.9 \pm 0.8^{*}$ & $80.1 \pm 0.8^{*}$ & $88.4 \pm 2.9$ & $8.9 \pm 0.8$ & $2.5 \pm 0.1^{* *}$ \\
\hline
\end{tabular}

Values are meanstS.E.M. of four chicks. " : Significant with respect to fed chicks. $(0.05>P>$ $0.01)$. ** : Significant with respect to fed chicks. $(P<0.01)$. 
whose component percentage to the total lipid was about $98 \%$, decreased $60 \%$ by fasting. Although phospholipid and total cholesterol content also decreased, these components accounted for less than $2 \%$ of the total lipid. The free fatty acid content per DNA, whose component percentage to the total lipid was $1 \%$ or less, showed a 1.8 -fold increase by fasting. The changes in the activities of LPL and HSL in the adipose tissue by fasting are shown in Table 4. There was an $82 \%$ reduction in
LPL activity and a $79 \%$ reduction in HSL activity by fasting. The LPL/HSL activity ratio showed no change by fasting. The change in plasma lipid composition by fasting is shown in Table 5. The triglyceride concentration showed a $61 \%$ decrease by fasting, and its percentage to the total lipid decreased from 27.8 to 15.3. The phospholipid concentration also showed a $27 \%$ decrease, but the percentage of this component to the total lipid showed no change. The free fatty acid concentration was

Table 3. Effect of fasting on the lipid composition of the abdominal adipose tissue (Experiment 2)

\begin{tabular}{lcccc}
\hline \hline Treatment & Triglyceride & Phospholipid & $\begin{array}{c}\text { Total } \\
\text { cholesterol }\end{array}$ & $\begin{array}{c}\text { Free } \\
\text { fatty acid }\end{array}$ \\
\hline Fed & $1866 \pm 248$ & $(\mathrm{mg} / \mathrm{mg}$ & DNA $)$ & \\
Fasted & $760 \pm 42^{* *}$ & $10 \pm 3$ & $14 \pm 3$ & $4 \pm 3$ \\
& \multicolumn{5}{c}{$8 \pm 4$} & $8 \pm 4$ \\
Fed & $98.5 \pm 0.8$ & $(\%$ of total lipid $)$ & \\
Fasted & $97.6 \pm 0.7$ & $0.5 \pm 0.1$ & $0.7 \pm 0.1$ & $0.3 \pm 0.1$ \\
\hline
\end{tabular}

Values are means \pm S.E.M. of four chicks. ${ }^{* *}:$ Significant with respect to fed chicks. $(\mathrm{P}<0.01)$.

Table 4. Effect of fasting on the activities of lipoprotein lipase (LPL) and hormone-sensitive lipase (HSL) in the abcominal adipose tissue (Experiment 2)

\begin{tabular}{lccc}
\hline \hline Treatment & LPL & HSL & $\begin{array}{c}\text { LPL/HSL } \\
\text { activity raito }\end{array}$ \\
\cline { 2 - 3 } & $(\mu \mathrm{Eq} / \mathrm{mg}$ DNA/hr $)$ & $13.9 \pm 1.7$ \\
Fed & $218.0 \pm 15.1$ & $16.3 \pm 2.1$ & $11.3 \pm 0.5$ \\
\hline
\end{tabular}

Values are means \pm S.E.M. of four chicks. ${ }^{* *}$ : Significant with respect to fed chicks. $(\mathrm{P}<0.01)$.

Table 5. Effect on fasting on plasma lipid composition (Experiment 2)

\begin{tabular}{|c|c|c|c|c|}
\hline Treatment & Triglyceride & Phospholipid & $\begin{array}{c}\text { Total } \\
\text { cholesterol }\end{array}$ & $\begin{array}{c}\text { Free } \\
\text { fatty acid }\end{array}$ \\
\hline \multicolumn{5}{|c|}{$(\mathrm{mg} / 100 \mathrm{ml})$} \\
\hline Fed & $236.4 \pm 24.4$ & $419.9 \pm 12.6$ & $177.8 \pm 8.8$ & $15.0 \pm 0.9$ \\
\hline Fasted & $93.0 \pm 2.9^{* *}$ & $304.5 \pm 15.6^{* *}$ & $189.3 \pm 5.8$ & $22.3 \pm 0.7^{* *}$ \\
\hline \multicolumn{5}{|c|}{ (\% of total lipid) } \\
\hline Fed & $27.8 \pm 1.7$ & $49.5 \pm 2.1$ & $20.9 \pm 1.3$ & $1.8 \pm 0.2$ \\
\hline Fasted & $15.3 \pm 2.5^{* *}$ & $50.0 \pm 2.0$ & $31.1 \pm 1.1^{* *}$ & $3.6 \pm 0.4^{* *}$ \\
\hline
\end{tabular}

Values are means \pm S.E.M. of four chicks. ${ }^{* *}$ : Significant with respect to fed chicks. $(\mathrm{P}<0.01)$. 
increased 1.5 -fold by fasting.

Experiment 3: The changes in triglyceride synthesis and fatty acid oxidation in chick liver in vivo and in vitro by fasting are shown in Table 6. The incorporation of $\left[1-{ }^{14} \mathrm{C}\right]$ acetate into total fatty acid decreased by $95 \%$ in vivo and by $96 \%$ in vitro by fasting, respectively. The incorporation of $\left[1-{ }^{14} \mathrm{C}\right]$ palmitate into triglyceride decreased by $96 \%$ in vivo and by $97 \%$ in vitro by fasting. As shown in Table 6 , the oxidation of $\left[1-{ }^{14} \mathrm{C}\right]$ palmitate to $\mathrm{CO}_{2}$ was enhanced 4.2-fold in vivo and 5.7-fold in vitro by fasting.

\section{Discussion}

There was a marked decrease in abdominal adipose tissue weight during 3 days of fasting (Table $1 \mathrm{~A}$ ). But there was no difference in the tissue weight between a 2-day or a 3-day fasting. Therefore, 2 days was chosen as the fasting duration. The alteration in abdominal adipose tissue weight in the present experiment is essentially in accord with previous reports ${ }^{17,18,33\rangle}$. Fasting caused an increase in plasma free fatty acid concentration which reached a peak after 1 day. And, after reach- ing a peak, there was a decline in the plasma free fatty acid concentration to the pre-fasting level (Table $1 \mathrm{~A})$. This result is similar to those described earlier in chicks ${ }^{1,19,24,33)}$.

As shown in Tables $2 \mathrm{~A}$ and $2 \mathrm{~B}$, fasting significantly decreased the dry matter content per DNA in adipose tissue without affecting the total DNA content. Among the components of dry matter, a marked decrease was observed in lipid content. VENDREY ${ }^{34}$ has reported that the DNA content of the fat pad is used to measure its cellular development on the assumption that DNA content is constant on a cellular basis. In other words, the total amount of DNA might indicate the cell number, and the dry matter/DNA ratio might indicate the cell size. The results described above indicate that the decrease in adipose tissue weight by fasting is a consequence of decreased cell size, being due chiefly to the decrease in lipid content. Table 3 indicates that fasting significantly decreased the triglyceride content per DNA, which occupied the largest portion of the adipose tissue lipid. This indicates that the decrease in lipid content is due mainly to the decrease in triglyceride

Table 6. Effect of fasting on triglyceride synthesis and fatty acid oxidation in the chick liver (Experiment 3)

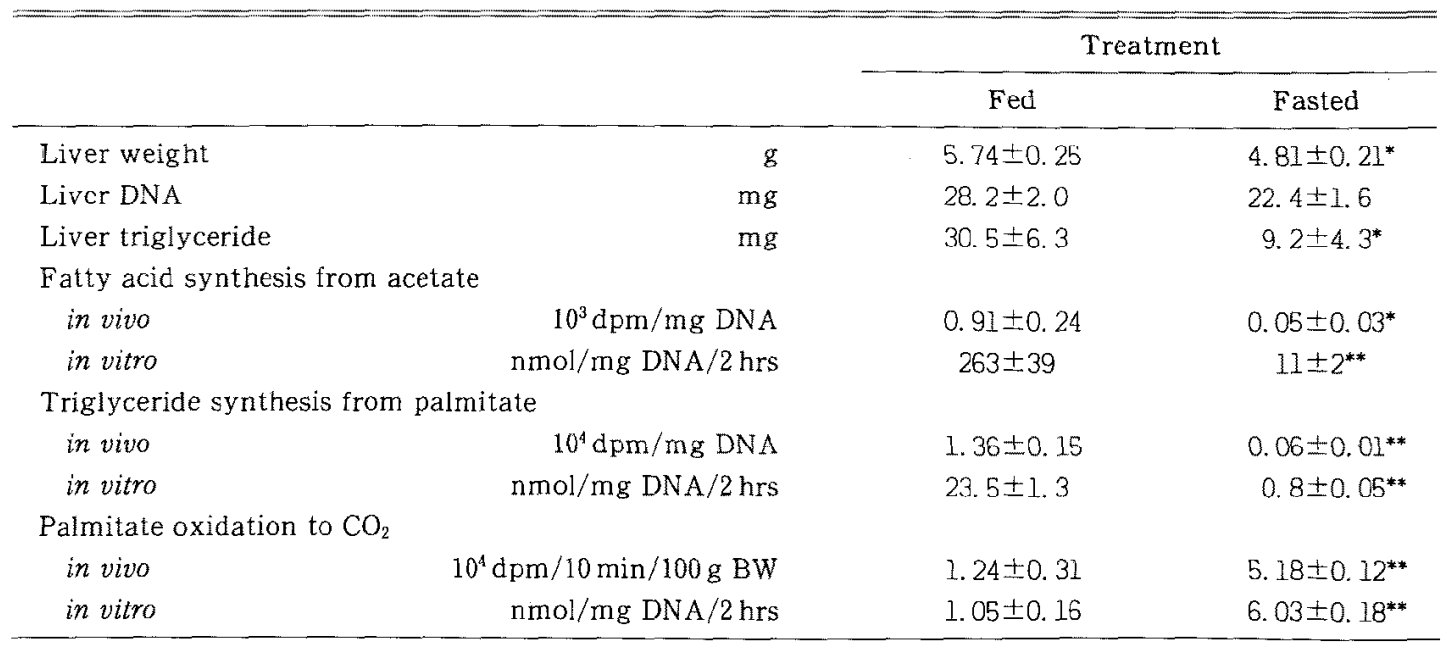

Values are means \pm S.E.M. for four chicks. ${ }^{*}$ : Significant with respect to fed chicks. $(0.05>P>0.01)$. ${ }^{* *}$ : Significant with respect to fed chicks. $(P<0.01)$. 
content.

Decreased triglyceride in the adipose tissue can occur due to the following factors; (a) a reduced rate of fatty acid uptake from blood, (b) an enhanced rate of fatty acid output into blood, (c) a decrease in blood triglyceride concentration, (d) a reduced rate of de novo triglyceride synthesis and/or enhanced rate of fatty acid oxidation in the adipose tissue and (e) the combination of (a)-(d).

Since the avian adipose tissue has very low lipogenesis and fatty acid oxidation ${ }^{21.2537)}$ activities, we first examined the contribution of factors (a) and (b) to decreased triglyceride in the adipose tissue by fasting. It is well known that the uptake of fatty acid from plasma triglyceride is mediated by LPL, and that the output of fatty acid from adipose tissue triglyceride is regulated by $\mathrm{HSL}^{28,29)}$. In mammals, it is well established that LPL activ. ity in the adipose tissue decreases when animals are starved ${ }^{6,7,11,15)}$. As shown in Table 4, fasting significantly reduced LPL activity in the adipose tissue. This result well supports the report by BorRon et $a .^{2)}$ who showed that LPL activity in the chicken adipose tissue is reduced by fasting for 12 or 72 hours. There have been similar reports by other workers ${ }^{15,16)}$ of a reduction in LPL activity in the chicken adipose tissue by fasting. The influences of fasting on HSL activity in the adipose tissue have been well studied in mammals ${ }^{26,29,35)}$, although there are discrepancies among the effects of fasting on HSL activity in the adipose tissue. On the contrary, in avian species, there is no information with regrad to the effects of fasting on HSL activity in the adipose tissue. Our results showed that fasting significantly reduced HSL activity in the adipose tissue (Table 4). This result is similar to the reports of STEFFEN et $a l^{31)}$ and LARKING and $\mathrm{NYE}^{20)}$ who showed that HSL activity in the adipose tissue in swines and in rats tends to be reduced by fasting for 24 or 72 hours. On the contrary, $\mathrm{RIZACK}^{30)}$ reported that more HSL activity could be extracted from the fat pads of starved rats than from those of fed rats. But, OkunA et al. ${ }^{27)}$ found that changes in HSL activity are significantly influenced by the way in which the activity is expressed. In the RizAcK report, HSL activity is expressed per wet weight of the adipose tissue. However, when expressed on a per cell basis, there is a possibility that the HSL activity of starved rats is lower than that of fed rats. This is because the wet weight of the adipose tissue greatly decreases during fasting whereas the cell number of the adipose tissue doesn't change. As shown in Table 4, the LPL/HSL activity ratio showed no change by fasting, being essentially in accord with the observation described above (Table $1 \mathrm{~B}$ ), although fat deposition in the adipose tissue was decreased. This result is different from the report of PATTEN ${ }^{29)}$ who has suggested that LPL and HSL in the adipose tissue show reciprocal change, and that a reduction in the LPL/HSL activity ratio would favour the diminution of body fat. But, in his report, lipolytic activity, not the net activity, of HSL was determined. Namely, they estimated the release of fatty acid or glycerol from free fat cells and used this as an index of HSL activity. Therefore, it is difficult to suppose in chicks treated by fasting that the change in LPL/HSL activity ratio is closely associated with changes in fat deposition in the adipose tissue as suggested by PATTEN $^{29)}$ and PAIK and YEARICK ${ }^{28)}$. These results described above suggest that a marked reduction in LPL acivity may be one of the factors responsible for the decrease in triglyceride in the adipose tissue by fasting. Secondly, we examined the contribution of factor (c) to the decrease in triglyceride by fasting. Table 5 indicates that there was a marked decrease, approximately 60\%, in plasma triglyceride concentration by fasting. This result suggests that in addition to the reduced activity of LPL in the adipose tissue, a marked decrease in the plasma level of triglyceride may also be one of the factors respon- 
sible for the decrease in triglyceride in the adipose tissue by fasting.

In chicks, triglyceride is synthesized almost exclusively in the liver, transported in the blood and taken up mainly by the adipose tissue and muscle ${ }^{21,25,37)}$. Table 6 indicates that fasting significantly reduced fatty acid synthesis from acetate in the chick liver in vivo and in vitro. This result well supports the report of TANAKA et al. ${ }^{32)}$ who showed that fatty acid synthesis from $1^{-14} \mathrm{C}$ acetate by liver slices is reduced by fasting.

LEVEILLE ${ }^{22)}$ also reported the reducing effect of fasting on in vivo fatty acid synthesis from acetate in the chick liver. As shown in Table 6 , fasting significantly reduced triglyceride synthesis from palmitate in the chick liver in vivo and in vitro. These results suggest that de novo triglyceride synthesis, namely triglyceride synthesis from both lipid precursor (fatty acid) and nonlipid precursor (acetate) in the chick liver is reduced by fasting. There was an enhancement in both in vivo and in vitro palmitate oxidation to $\mathrm{CO}_{2}$ in the chick liver by fasting (Table 6). These results described above suggest that both a reduced rate of triglyceride synthesis and an enhanced rate of fatty acid oxidation in the liver may be responsible for fasting-induced hypotriglyce-ridemia.

From the above results, it is reasonabie to assume that triglyceride diminution in the adipose tissue by fasting is attributable to the combination of reduced LPL activity in the adipose tissue and decreased triglyceride in plasma resulting from both the reduced rate of triglyceride synthesis and the enhanced rate of fatty acid oxidation in the liver.

Furthermore, it is necessary to investigate the contribution of factor (d) toward the decrease in triglyceride in the adipose tissue by fasting, although avian adipose tissue has very low lipogenesis and fatty acid oxidation ${ }^{21,23,25)}$ activities.

\section{Acknowledgment}

The present work was supported by a Grant-in-Aid (No. 56760203) for scientific reseach from Japanese Ministry of Education, Science and Culture.

\section{References}

1) Aramaki, T., Y. Karasawa and M. Inagami, Effect of glucagon on plasma glucose, free fatty acids, alpha-amino nitrogen non protein nitrogen and total protein concentrations and hematocrit values in fed and fasted adult female chickens. Japan. Poultry Sci., 13 : 141149. 1976. (in Japanese).

2) BorRon, D.C., L.S. JENSEN, M.G. McCARTNEY and W.M. BRITTON, Comparision of lipoprotein lipase activities in chickens and turkeys. Poultry Sci., $58:$ 659-662. 1979.

3) Boxer, G.E. and D.STetTen, Jr., The role of thiamine in the synthesis of fatty acids from carbohydrate precursors. J. Biol. Chem., 153 : 607-616. 1944.

4) BRAGDON, J. H., Lipids and steroid hormones in clinical medicine. (SUNDERMAN, F.W. et al., eds.) 10-14. Lippincott. Philadelphia. 1960.

5) Burton, K., $A$ study of the conditions and mechanism of the diphenylamine reaction for the colorimetric estimation of deoxyribonucleic acid. Biochem. J., $62: 315-323.1956$.

6) Cherkes, A. and R.S. Gordon, Jr., The liberation of lipoprotein lipase by heparin from adipose tissue incubated in vitro. J. Lipid Research., 1: 97-101.1959.

7) CRYER, A., Tissue lipoprotein lipase activity and its action in lipoprotein metabolism. Int. J. Biochem., 13 : 525-541. 1981.

8) Daniel, A.M. and D. Rubinstein, The effect of fasting on the esterification of plamitate by rat epididymal adipose tissue in vitro. Can. J. Biochem., 45 : 965-972. 1967.

9) FolCh, J., M. Lees and G.H. Sloane-Stanley, A simple method for the isolation and purification of total lipids from animal tissues. J. Biol. Chem., 226 : 497-509. 1957.

10) Goodridge, A, G., The effect of starvation and starvation followed by feeding on enzyme activity and the metabolism of $\left[\mathrm{U}-{ }^{14} \mathrm{C}\right]$ glucose in liver from growing chicks. Biochem. J., 108 : 667-673. 1968.

11) HARTMAN, A.D., Lipoprotein lipase distribution in rat adipose tissues: effect on chylomicron 
Effect of Fasting on Adipose Tissue Accumulation

uptake. Am. J. Physiol., 232 : E 316-E 323. 1977.

12) Hasegawa, S., K. Sato, Y. Hikami and T. Mizuno, Effect of estrogen on adipose tissue accumulation in chicks, with reference to changes in its chemical composition and lipase activity. Jpn. J. Zootech. Sci., 51 : 360-367. 1980.

13) Hasegawa, S., K. Sato, Y. Hikami and T. Mizuno, Effect of estrogen on adipose tissue accumulation in chicks, with reference to changes in triglyceride synthesis and fatty acid oxidation. Jpn. J. Zootech. Sci., 51 : 673679. 1980.

14) Hasegawa, S. T. Nimori, K. Sato, Y. Hikami and T. Mizuno, Effects of estrogen on triglyceride metabolisim in chick liver. Jpn. J. Zootech. Sci., 53 : 699-706. 1982.

15) HollenBerg, C.H., Effect of nutrition on activity and release of lipase from rat adipose tissue. Am. J. Physiol., 197 : 667-670. 1959.

16) HusBands, D.R., The distribution of lipoprotein lipase in tissues of the domestic fowl and the effects of feeding and starving. Br. Poult. Sci., $13: 85-90,1972$.

17) JANSEN, G.R.,C.F. Hutchison and M.E. ZaneTt, Effect of dietary fat or starvation on coversion of $\left[{ }^{14} \mathrm{C}\right]$ glucose into fat and turnover of newly synthesized fat. Studies on liposenesis in vivo. Biochem. J., 99 : 323-332. 1966.

18) Jansen, G.R., M.E. ZANETTi and C.F. HuTCHison, Effects of starvation and re-feeding, and studies on cholesterol synthesis. Studies on lipogenesis in vivo. Biochem. J., $99: 333-340$. 1966.

19) Langslow, D.R., E.J. Butler, C.N. Hales and A. W. PEARSON, The response of plasma insulin, glucose and non-esterified fatty acids to various hormones, nutrients and drugs in the domestic fowl. J. Endocr., 46 : 243-260. 1970.

20) LaRKING, P.W. and E.R. NYE, The effect of dietary lipids on lipolisis in rat adipose tissue. Brit. J. Nutr., 33 : 291-302. 1975.

21) Leveille G.A., E.K. O'Hea and K. Chakrabarty, In vivo lipogenesis in the domestic chicken. Proc. Soc. Exp. Biol. Med., 128 : 398-401. 1968.

22) LeVEILLE, G.A., In vivo fatty acid and cholesterol synthesis in fasted and fasted-refed chicks. J. Nutr., $98: 367-372.1969$.

23) Levellle, G.A., D.R. Romsos, Y.Y. YeH and E. K. O'HEA, Lipid biosynthesis in the chick. A considaration of site of synthesis, influenece of diet and possible regulatory mechanisms. Poultry Sci., 54 : 1075-1093. 1975.

24) Nir, I., V. LeVy and M. PEREK, Response of plasma glucose, free fatty acids and triglycerides to starving and re-feeding in cockerels and geese. Br. Poult. Sci., $14: 263-268$. 1973.

25) O'HeA, E.K. and G.A. Leveille, Lipogenesis in isolated adipose tissue of the domestic chick (Gallus domesticus). Comp. Biochem. Physiol., 26 : 111-120. 1968.

26) Okuda, H., I. Yanagi and S. Full, The mechanism of in vitro stimulation of lipolysis by adrenaline. J. Biochem., 59 : 438-442. 1966.

27) Okuda, H., I. Yanagi, F.J. Sek and S. Fu.ll, J. Biochem., 68 : 199-203. 1970.

28) PAIK, H. S. and E.S. YEARICK, The influence of dietary and meal frequency on lipoprotein lipase and hormone-sensitive lipase in rat adipose tissue. J. Nutr., 108 : 1798-1805. 1978.

29) Patten, R.L., The reciprocal regulation of lipoprotein lipase activity and hormone-sensitive lipase activity in rat adipocytes. J. Biol. Chem., 245 : 5577-5584.1970.

30) RızACK, M. A., An epinephrine-sensitive lipolytic activity in adipose tissue. J. Biol. Chem., 236 : 657-662. 1961.

31) Steffen, D.G., M.C. Arakelian, G. Phinney, L.J. Brown and H.J. MERsmann, Effect of nutritional status on swine adipose tissue lipolytic activities. J. Anim. Sci., 52 : 1306-1311. 1981.

32) TANAKA, K., T. Sen and K. Shigeno, The effect of fasting and refeeding on lipids of serum and liver in the meat-type chicken. Jap. J. Zootech. Sci., 46 : 396-402. 1975. (in Japanese).

33) Tanaka, K., K. Kenmochi, S. Ohtani, S. Ohtani, C.M. COLLADO and K. SHIGENO, Effects of fasting and fasted-refeeding on gluconeogenic and glycolytic enzymes and acyl-CoA synthetase in growing chicks. Jpn. J. Zootech. Sci., 55 : 780 $-788.1984$.

34) Vendrey, R., The Nucleic Acids. Vol, 2. 155-180. Academic Press. New York. 1955.

35) WISE, L.S. and R.L. JUNGAS, Evidence for a dual mechanism of lipolysis activation by epinephrine in rat adipose tissue. J. Biol. Chem., $253: 2624-2627.1978$.

36) YEH, Y.Y. and G.A. LevelLLE, Hepatic fatty acid synthesis and plasma free fatty acid levels in chicks subjected to short periods of food restriction and refeeding. J. Nutr., 100 : 13891397. 1970.

37) YEH, Y.Y. and G.A. LeVeILLE, In vitro and in vivo restoration of hepatic lipogenesis in fasted chicks. J. Nutr., 101 : 803-810. 1971. 


\title{
絶食による鶏の脂肪組織の蓄積, 特にその化学成分, 脂質成分およびリパーゼ活性に対する影響
}

\author{
長谷川 信・川上智弘・本田和久 ・氷上雄三 \\ 神戸大学農学部, 神戸市灘区 657
}

\begin{abstract}
絶食による舀の体脂肪減少の機構を調べる日的で，絶食処理鷄の腹膣内脂肪組織を用いて，その化学 成分，脂質成分、リバーぜ（リポプロテインリパーゼと本ルモン感受性リパー山゙）活性および肝淢トリ グリセリド合成能の変化を検討した， 3 週龄の白色レグホーン雄雊を用い，2 日間の絶食を行なった。絶 食により，腹腔内脂肪組織量は有意に減少した，化学成分において，総 DNA 量に変化はなかったか， DNA 単位重量当りの乾物量に有意な減少が見られた，さらに乾物成分のうち，乾物の約 $90 \%$ を占める 脂質の減少が顕著で, 対照区の $41 \%$ の値を示した。また，脂質成分では，脂質の大部分を占めるトリグ リセりドに顕著な減少が認められ，対照区の $41 \%$ 值を示した. 徒って, 絶食に上る腹腔内脂肪組織量 の減少は，主としてトリグリセリド量の減少に基づいた，細胞容量の減少によるものであることが示唆 されたリリポプテインリパーゼおよびホルモン感受性りパーゼは, 対照区に対して，おのおの $18 \%$ お よび $21 \%$ の活性值を示したが, (リポプロテインリパーゼ)/(ホルモン感受性リパーゼ) 活性比に変化

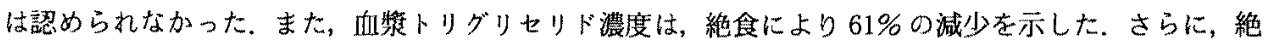

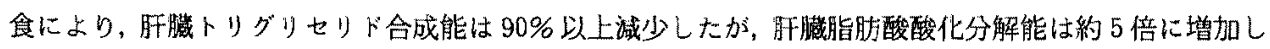
た、以上の結果に基づき，絶食による，腹腔内脂肪組織に肪ける，トリグリセリドの減少機構について 考察した.
\end{abstract}

日畜会報, 65 (2)：89-98，1994 